OPEN ACCESS

Edited by:

Krithi K. Karanth

Centre for Wildlife Studies, India

Reviewed by:

Viorel Dan Popescu,

Ohio University, United States

Jacalyn Mara Beck,

Michigan State University,

United States

*Correspondence:

Annelie Sjölander-Lindqvist annelie.sjolander-lindqvist@gu.se

Specialty section:

This article was submitted to

Conservation,

a section of the journal

Frontiers in Ecology and Evolution

Received: 22 September 2019

Accepted: 15 April 2020

Published: 05 June 2020

Citation:

Sjölander-Lindqvist A, Risvoll C,

Kaarhus $R$, Lundberg AK and

Sandström C (2020) Knowledge

Claims and Struggles in Decentralized Large Carnivore Governance: Insights

From Norway and Sweden.

Front. Ecol. Evol. 8:120.

doi: 10.3389/fevo.2020.00120

\section{Knowledge Claims and Struggles in Decentralized Large Carnivore Governance: Insights From Norway and Sweden}

\author{
Annelie Sjölander-Lindqvist ${ }^{1 *}$, Camilla Risvoll ${ }^{2}$, Randi Kaarhus ${ }^{3}$, Aase Kristine Lundberg ${ }^{2}$ \\ and Camilla Sandström ${ }^{4}$ \\ ${ }^{1}$ School of Global Studies \& Gothenburg Research Institute, University of Gothenburg, Gothenburg, Sweden, ${ }^{2}$ Nordland \\ Research Institute, Bodø, Norway, ${ }^{3}$ Department of International Environment and Development Studies, Faculty \\ of Landscape and Society, NMBU - Norwegian University of Life Sciences, Aas, Norway, ${ }^{4}$ Department of Political Science, \\ Umeå University, Umeå, Sweden
}

Ensuring sustainable carnivore populations while simultaneously sustaining active and viable pastoral communities often creates conflicts that are difficult to resolve. This article examines how different knowledge systems meet and interact in large carnivore governance in Norway and Sweden. Drawing on a broad range of sources, including observations in meetings, public documents, reports and interviews, in addition to local and national newspaper clippings and internet sites, we study two processes of regional carnivore management (Nordland, Norway and Jämtland, Sweden). We explore how different forms of knowledge have been mobilized, reproduced, transferred and legitimized in policies and regulations in these two processes. Furthermore, we examine the interplay between scientific and experience-based knowledge at different levels and scales in both countries. In Norway, "clear zoning" has been established as a basic management instrument to achieve national "population goals" for carnivores. We show how the locally situated knowledge - in our account represented through the Regional Large Carnivore Committee (RLCC), which includes political parties' and Sami Parliament representatives - experiences real barriers by being overruled by the national Ministry of Climate and Environment, 2016 in their process of revising the carnivore management plan (CMP). In Sweden where the management of large carnivores is devolved to regional authorities and stakeholder-based Wildlife Management Delegations (WMDs), attempts to regionally solve conflicts are often overthrown by the national environmental protection agency or through court cases initiated by the environmental movement. Hence, compromises that potentially could solve conflicts are undermined. The analysis shows that while carnivore governance in both countries are founded on decentralized management authority at the regional level, local actors struggle for their views, experiences and knowledge to be acknowledged and counted as valid in the management process. While the decentralized management 
model opens for inclusion of different knowledge systems, this system has yet to acknowledge the challenges of knowledge being dismissed or marginalized across governance levels and scales.

Keywords: large carnivore management, pastoral communities, decentralization, knowledge spheres, conflicts

\section{INTRODUCTION}

Various international conventions recognize democratic decentralization of natural resource management as a desirable, or even essential, measure for ensuring sustainability when states address environmental challenges (Agrawal and Chatre, 2006; Hayes and Persha, 2010). There are references to democratic decentralization as a key component of good governance in the numerous reforms and guiding principles emanating from international agreements and treaties. The Rio Declaration on Environment and Development and Agenda 21, both adopted in 1992 (and highly pertinent in the context of this study), advise states to implement policies and principles that support inclusion of local people and populations in the management of common resources (United Nations, 2011). The United Nations (1992) also states that biodiversity conservation initiatives should be decentralized to the lowest appropriate level. More recently, the 2030 Agenda for Sustainable Development followed this line by promoting efforts to raise awareness of the importance of engaging local actors in decision-making processes related to achieving the Sustainable Development Goals. As parties to these conventions and agreements, nation states have made various attempts to decentralize management of natural resources to regional and local governance levels. Each country has chosen its own trajectory and specific mix of modalities and powers, ranging from some form of administrative decentralization to more comprehensive forms of democratic decentralization or devolution (Manor, 1999; Sandström et al., 2009; Hongslo et al., 2016; Hansson-Forman et al., 2018).

Two neighboring countries, Norway and Sweden, have chosen different decentralization paths in their efforts to ensure the conservation of large-carnivore populations. These conservation measures relate specifically to the Convention on the Conservation of European Wildlife and Natural Habitats (also referred to as the Bern Convention), and for Sweden, the Directive on the Conservation of Natural Habitats and of Wild Fauna and Flora (also referred to as the Habitats Directive) (European Commission, 1992). Both governments also aim to sustain active and viable pastoral communities. However, Norway has decentralized management tasks to indirectly elected politicians through eight RLCCs, while Sweden has decentralized management of large carnivores to the regular regional authorities, and 21 regional WMDs, which include

Abbreviations: CA, Carnivore Agreement; CAB, County Administrative Board; CBD, Convention on Biological Diversity; CG, County Governor; CMP, Carnivore Management Plan; FCS, Favorable Conservation Status; ILO, International Labor Organization; MAF, Ministry of Agriculture and Food; MCE, Ministry of Climate and Environment; NEA, Norwegian Environmental Agency; NHA, Norwegian Hunting Association; NLCR, Northern Large Carnivore Region; NNI, Norwegian Nature Inspectorate; RLCC, Regional Large Carnivore Committee; SEPA, Swedish Environmental Protection Agency; WMD, Wildlife Management Delegation. both politicians and representatives of selected stakeholder organizations (Risvoll et al., 2016; Hansson-Forman et al., 2018; Sandström et al., 2018).

Due to the differences in their implementation of international norms on large carnivore governance (through political and corporate channels in Norway and Sweden, respectively) differences in terms of outcomes of their decentralization processes may have been expected. However, this article shows clear parallels in ways that partly conflicting normative priorities embedded in different international conventions pose real problems in both countries at local and regional levels. Based on previous research, we argue that problems associated with at least three interconnected aspects must be analyzed to understand the processes and interactions played out in these two cases. We show how: (1) Conflicting conventions, and the processes that translate them into national policy, create multifaceted goals; (2) Decentralization to meet policy goals creates conflict between levels; and (3) The inclusion of various actors at different levels creates conflicts between knowledge spheres.

With knowledge spheres, we refer to the multiple ways of knowing, such as science and indigenous knowledge that are grounded in different epistemological and ontological assumptions, but also to the actors who represent these ways of knowing (Sjölander-Lindqvist et al., 2015). The processes of translation of international conventions and decentralization into local contexts may explain why the decentralization of natural resource management is contentious and contradictory, how and why it may create conflicts, and why it results in controversies and unsettled outcomes.

In this study, we compare empirical manifestations of these three processes through the works of the RLCC of the Nordland region in Norway and the WMD of the Jämtland region in Sweden. We first analyze how international norms are translated into large carnivore management policies in Norway and Sweden. In a second step, we analyze the intervention strategies that have been formulated based on these norms, how they are put into practice through decentralized management in the two countries, and how these strategies lead to associated controversies. Finally, in a third step, we analyze how the use of specific ways of knowing and power generate selfgoverning subjects, but also how these different ways of knowing are mobilized to contest the dominant management approaches, which are reproduced and legitimized in policies, regulations and management interventions in our two cases. By comparing these cases, we contribute to the discussion of decentralized decision-making in the controversial issue of biodiversity (particularly carnivore-related) management, and the role of local/indigenous knowledge in such highly contentious cases. 


\section{DECENTRALIZATION AND WAYS OF KNOWING}

"Decentralization" can be defined as "the transfer of power from the central government to actors in institutions at lower levels in a political-administrative and territorial hierarchy" (Larson and Ribot, 2005, p.3). Manor (1999, p.5) has published a fairly simple typology that can be presented along an axis ranging from "deconcentration" of certain tasks and responsibilities (also called "administrative decentralization"), where the decentralized level remains upwardly accountable, to "democratic decentralization," a form involving the transfer of both power and resources to lower level authorities (Manor, 1999, p.6). Strong forms of democratic decentralization will also involve downward accountability at the decentralized level. While downward accountability is crucial for democratic decentralization, a certain degree of upward accountability will usually remain, resulting in a mix of upward and downward accountabilities that can create challenges, especially when different ways of knowing inform decisions at different levels. Generally assumed benefits of democratic decentralization include increases in legitimacy, participation, effectiveness, and sustainability. These benefits can be further strengthened if decision-makers successfully combine various ways of knowing or at least try to intersect different ways of knowing in natural resource management, as well as provide opportunities to participate in management and share the responsibility for policy outcomes (Berkes, 2010; SjölanderLindqvist et al., 2015).

Managing different ways of knowing, and thus knowledge spheres, is essential for effective decentralization and collaborative governance (Emerson and Nabatchi, 2015); we simply need a lot of knowledge and expertise of different kinds to be able to make well-grounded decisions. Greater public engagement through consultation, negotiation, and cooperation in policy design and implementation can generate a more heterogeneous pool of knowledge, which in turn can improve the quality of decisions (Primmer and Kyllönen, 2006). Collectively agreed decisions that acknowledge local concerns and ways of knowing are more likely to be socially and politically accepted and can help to reduce conflicts among parties involved in a process (Hansson-Forman et al., 2018). Furthermore, interaction across or pooling of knowledge spheres can promote development of new knowledge (Mårald et al., 2015), which may also be more context- or place-based (Stoffle et al., 2013; Sjölander-Lindqvist and Cinque, 2014).

Including different ways of knowing in decision-making regarding natural resource management, requires the parties involved to deal with epistemological as well as practical aspects of relating to different knowledge spheres (Risvoll and Kaarhus, in press). Ecosystems are complex, and their management requires the institutional capacity to continuously test and develop an understanding of their dynamics. Such insights and extended knowledge often emerge when people meet, discuss and share their "local knowledge," "traditional ecological knowledge" or "indigenous knowledge" (Folke, 2004; Eira and Sara, 2017). In order to use this knowledge in decisionmaking, institutions need to take account of the experiences of different resource users, as they interact with ecosystems on a daily basis, and often over long time spans, to secure their livelihoods (Dondeyne et al., 2012; Stoffle et al., 2013). However, integrating for example technical and scientific ways of knowing with local, traditional, and indigenous knowledge in decentralized decision-making processes tends to be challenging for several reasons. Two major obstacles seem to be a perception among both scientists and policymakers that local knowledge lacks validity and reliability (Failing et al., 2007). Local knowledge is not usually institutionalized in ways that provide robust foundations for systematically challenging outcomes of scientific knowledge production. Thus, differences in how these different ways of knowing - and the resulting knowledge spheres are institutionalized - easily result in imbalances in the way the respective spheres influence the management of ecosystems and natural resources. However, both the climate and the biodiversity crisis has rendered scientists and policymakers to call for the acknowledgment and inclusion of a multitude of different ways to understand and engage with the world. For example, indigenous and local knowledge are not only increasingly considered as equally meaningful, but also critical to our efforts to understand complexity and create the possibility for transformational social change (IPBES, 2019; IPCC, 2019).

Despite extensive research on decentralization and collaborative governance in natural resource management, Hongslo et al. (2016) recognize a need for more refined theoretical explanations of the failure of some participatory measures to encourage consensual solutions and provide empowerment in political processes and policy implementation. In addition, Emerson and Nabatchi (2015) recognize a complementary need to focus on the concrete situations and conditions of participatory measures to explain their outcomes. Thus, in this article we aim to address both concerns in our analysis of carnivore management.

\section{ANALYTICAL FRAMEWORK}

Our approach is inspired by the study of environmental protection through decentralization of forest governance and theoretical framework presented in Environmentality (Agrawal, 2005), which describes the constitution of the Kumaon forest councils in the 1930s as an early attempt to include local people in the management of natural resources in northern India. Drawing on the concept of "governmentality" (cf. Foucault, 2010), Agrawal holds that this decentralization served to "governmentalize the environment," and suggests that this governmentalization was accomplished through "the creation, activation, and execution of new procedures for surveying, demarcating, consolidating, protecting, planting, managing, harvesting and marketing forests" (p.12).

More generally, studies in governmentality deal with how power can be repressive, but also productive in terms of producing and promoting particular ways of knowing. Individuals or groups are made "governable" through the communication between the state and the public as well as through technologies and rationalities employed by the 
state. These rationalities create specific subject positions for the individuals or groups by advocating for, e.g., an active, participatory role in the management of common resources. In our case with large carnivores, the individual is assumed to take co-responsibility for the development of the large carnivore policy, operating within a formal and decentralized institutional arrangement. In this case, the subject position could, for instance, be the reindeer herder who carries generationaldeveloped knowledge regarding how climate change affects reindeer grazing and therefore may be more vulnerable to large carnivore presence. Another example could be the manager, who often is a trained natural scientist and part of the bureaucracy and has learned that objectivity and effectiveness build on the calculable (Cinque, 2008). Foucault (1991) refers to this as "the conduct of conduct."

The concept of environmentality is more specifically used to analyze power in relation to environmental management at various political levels (e.g., Bäckstrand and Lövbrand, 2006). The concept is useful as a lens to view the environment as not only a biophysical entity, but also as a site of power and knowledge where truths are made, circulated and remade (Agrawal, 2005). An "environmentality" approach thus directs our analysis to include three interrelated aspects: (1) the production of rationalities of rule, i.e., on what basis rules are set up and determined; (2) the strategies of intervention, and finally (3) the - sometimes contested - generation of "environmental subjects" at levels where different knowledge spheres interact, that is subjects in power-knowledge processes.

The first aspect - the production of rationalities of rule concerns how power produces and constitutes the reality that subjects can act upon (Foucault, 1980). What is considered authoritative knowledge will facilitate or promote certain ways of understanding the environment - including large carnivores - while impeding others. The dominant way of seeing and perceiving the environment is through a scientific lens (Rutherford, 2007). The assumed objectivity of science tends to give it a powerful voice to speak for the environment and how it should be managed. Based on natural science, rules and norms shaping governance and management methods are established through, for example, international treaties, thereby normalizing particular policies for environmental management and authorizing certain experts to act in management (Goldman et al., 2011). However, the international treaty system is still fragmented with a multitude of partly divergent norms, which are also reflected throughout the governance and management of large carnivores on the Scandinavian peninsula. This may lead to conflicting priorities between different conventions, and the creation of multifaceted and conflicting goals when they are embedded in policy. For example, reindeer herders may have to change their traditional practices in order to prevent further damage by large carnivores when the political decision to support large carnivore revival leads to an increase in the populations. The second aspect - the strategies of intervention - concerns problem-setting, direction-setting, and decision-making. In the decentralization process, value-driven bureaucratic and local circumstances and requirements may lead to disagreements regarding optimal or viable strategies to reach policy goals, actions to take, and incentives, sanctions or other measures to promote them, thereby creating conflicts between levels (Vinzant and Crothers, 1998; Winter, 2007). Important elements of strategies of intervention thus include ideas regarding the most suitable administrative level to manage a specific problem (e.g., decentralization), who should be included and on what grounds. This includes management solutions deemed most appropriate (e.g., zoning, protective hunting, or adaptive management) when implementing overarching norms, in which the management at both regional and national levels according to the intentions of the different conventions and rules, should (need to) assess both the material and the immaterial dimensions and consequences of large carnivore presence. For example, changed traditional practices may lead to reevaluated traditional knowledge, which decision-makers should give appropriate attention to in order to live up to the norms of the regulatory framework.

The third aspect in this environmentality framework is the generation of environmental subjects in power-knowledge processes - how they are expected to act as agents in the service of environmental regulation (or may resist such regulation), and their understanding of local natural resource governance. Strang (2009) argues that "there is a need to consider not just the formal institutions" (p.5), but also the "social complexities, diverse subcultural perspectives, and material opportunities and constraints" (p.6; cf. Ingold, 2000; Rival, 2001). Diverse understandings and inclusion of stakeholders in the decision-making process provide scope for conflicts between ways of knowing because of what knowledge is regarded as valid from a bureaucratic perspective (Failing et al., 2007). The result tends to be the establishment of a knowledge hierarchy, where, for example, experience-based knowledge is considered subordinate and local livelihood-based discourses are dismissed, while scientific models and experts' understanding are seen as providing superior knowledge for handling pressing issues (Agrawal, 2005; Sjölander-Lindqvist, 2008). Hence, technological and scientific based knowledge confronts local communities' skills and understandings (Scott, 1998). While Agrawal (1995) highlights the need to recognize multiple ways of knowing to counteract reductionist tendencies in environmental management, decision-making in natural resource management contexts has been, and to a large extent still is, based on expert-led, scientific evidence (Woodroffe and Redpath, 2015).

\section{CASES AND METHODS}

The work presented in this paper is a comparative case study of two processes, or rather attempts, to regionally manage large carnivores in northern Norway (Nordland) and northern Sweden (Jämtland). We specifically focus on the process of revising the CMP for the Nordland Region in 2015-2018, and the attempt to implement the nationally decided policy instrument tolerance levels - in Jämtland, as comparative windows onto the debate on decentralization and the larger discussion on democratic governance. As cases they are both similar enough and separate enough to be treated as instances of the same phenomenon (Ragin, 1992, p.1), i.e., decentralized carnivore 
governance. Both cases involve struggles to balance indigenous and local experience-based knowledge with quantitative scientific assessments of variables such as carnivore population sizes, distributions, genetics, social behavior, and effects on large herbivore populations in decision-making regarding the highly controversial issue of carnivore and pastoralist coexistence. Through following the two processes we were able to identify what these cases were "cases of" (Becker, 1992). We refer to the comparison presented here as "horizontal," which requires, according to Bartlett and Vavrus (2017, p.53), attention to "how historical and contemporary processes have differently influenced" each case, but also facilitates discussion of how such processes have led to similar outcomes. With both cases relating to the same level - the regional governance levels in Nordland and Jämtland - we also address units of analysis that are" fairly equivalent" (Bartlett and Vavrus, 2017, p. 53).

The regional settings are the geographical areas of Nordland County in Norway and Jämtland County in Sweden. Nordland is one of eight RLCCs in Norway, while Jämtland is one of 21 WMDs in Sweden, and part of the Northern Large Carnivore Region (NLCR) (Figure 1).

Nordland has a ca. $500 \mathrm{~km}$ north-south border with Sweden from around $68^{\circ}$ north at the eastern side of the county, while Jämtland borders Norway south of Nordland County. There are about 15,000 domesticated reindeer in 12 reindeer herding districts in Nordland (County Governor, 2017), and about 47,000 in 12 districts in Jämtland (Sametinget, 2019). Reindeer husbandry is a traditional Sami practice that has been carried out throughout Sápmi (the Saìmi homelands) in northern parts of Norway, Sweden, Finland and Russia for centuries. Reindeer (Rangifer tarandus tarandus) are a migratory species, and the traditional basis of Sami reindeer herding is transhumance, which involves seasonal movement of reindeer between fixed summer and winter pastures (Sara, 2001; Joks et al., 2006). It involves use of climatically marginal pasture resources and is an extensive land-use practice. Rights to land are critical for Sami reindeer herders, and property laws in Norway, Sweden, and Finland are based on old doctrines of customary rights (Allard, 2015). Access to pastures has been institutionalized since 1751, when the Lapp Codicil was enacted to regulate cross-border migration between Norway and Sweden. Reindeer husbandry is carried out on both state-owned and privately owned land in all the FennoScandinavian countries, and close to $40 \%$ of the countries' land area is used for reindeer herding (Allard, 2011). However, these land areas are also used for agriculture, mining, forestry, tourism, and other leisure activities, creating competition for natural resources and fragmented pastures for reindeer herding (Risvoll, 2015; Kløcker Larsen et al., 2017). Impacts of climate change and carnivore pressure exacerbate already sensitive land-use areas (Risvoll and Hovelsrud, 2016).

In our case study areas, carnivores roam across vast tracts and frequently cross the border between Norway and Sweden (where the carnivore density is higher) when habitats are available and the carnivores need to extend their habitats (Swenson and Andrén, 2005; Gangaas et al., 2013). Reindeer comprise an important food source for large carnivores, and large carnivores cause severe losses in both Nordland and Jämtland). Wolverines are particularly dependent on reindeer during winter for their survival (Aronsson and Persson, 2017), while for instance brown bears prey on reindeer primarily during the calving season in May and June (Sivertsen, 2017).

In our inquiry we drew upon a broad range of sources, including observations in meetings, public documents, reports, local and national media and internet sites, semi-structured, open, and follow-up interviews, as well as informal conversations with RLCC and WMD members as well as representatives from interest organizations, local and regional authorities and reindeer herders (Table 1). We also interviewed herders who are not members of the RLCC or WMD about issues related to reindeer-carnivore coexistence and carnivore management. In the research design, it was considered important to choose methods that would enable collection of new information, provide flexibility to explore different topics in depth with the informants, and enable procedural adaption. Hence, data were collected with openness to new connections to allow critical interrogation of engagement and the manifestation of people's meanings, intentions, and aspirations. This requires sensitivity to the tangible and associative values of those concerned and involved, and the circulating discourses, multiple contestations and regimes of power enacted, and confirmed within the participatory field (Shore et al., 2011). The interviews therefore covered both a number of key general questions and themes but the conversations with informants were also intended to encourage their reflection, thoughts, associations, and questions. In addition to audio recording the interviews, we took complementary notes. Questions asked included: Do you as a representative or stakeholder feel that your voice has been heard in this process? Can you elaborate on the main challenges as you see it, in the revision process (Norway), or for Sweden, the implementation of new intervention strategies? (see Table 1). The type of analyzed documents included parliamentary and management documents, hearings and media coverage of the process.

In Norway, we attended nine RLCC meetings in 20162018 as observers. In addition to the board members, various other actors have attended these meetings from time to time, such as representatives of pastoral organizations, the NHA, the NEA, the NNI, and other invited speakers. We were usually two observers who took written notes of all statements made during these meetings. After each meeting, we compared notes, identified major issues of controversy expressed during the meeting, evaluated possible interpretations and agreed on what statements were representative and significant for the analysis and presentation of our results. Interviews and numerous conversations with relevant local-, regional- and national-level actors and agencies were also conducted during 2016-2018. Interviewees included representatives of the Nordland RLCC $(n=5)$, the NNI $(n=2)$, the CG $(n=3)$, officials from municipalities in the Salten region $(n=2)$, farming and herding associations $(n=2)$ and a regional representative from one environmental organization. Some of these informants have been interviewed several times. Interviews lasted usually about an hour. We were also observers at relevant meetings and seminars with pastoralists' organizations and local government 


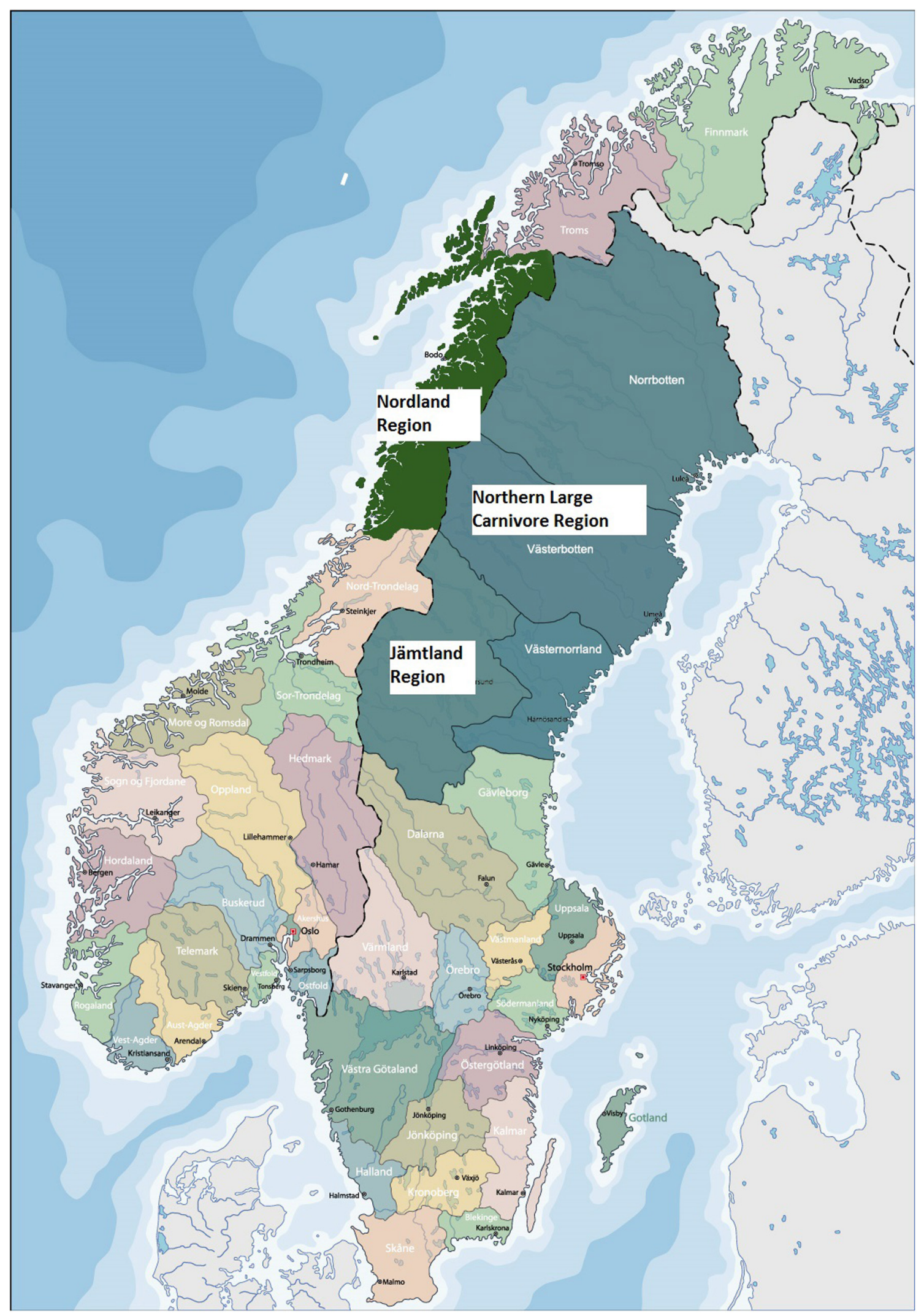

FIGURE 1 | Map of case study areas. 
TABLE 1 | Analytical dimensions, units of analysis, methods, and research questions.

\begin{tabular}{|c|c|c|c|}
\hline $\begin{array}{l}\text { Aspect of } \\
\text { environmentality }\end{array}$ & Cases & Units of analysis/informants & Methods and research questions \\
\hline $\begin{array}{l}\text { The production of } \\
\text { rationalities of rule (see } \\
\text { section "Problems } \\
\text { Associated With Production } \\
\text { of Rationalities of Rules and } \\
\text { Conflicting Norms") }\end{array}$ & $\begin{array}{l}\text { Norway } \\
\text { Sweden }\end{array}$ & $\begin{array}{l}\text { International treaties/national regulations on } \\
\text { large carnivores and indigenous peoples }\end{array}$ & $\begin{array}{l}\text { Policy and document analysis } \\
\text { Which of the international norms on large } \\
\text { carnivores/indigenous rights/have been implemented and } \\
\text { how? }\end{array}$ \\
\hline \multirow[t]{2}{*}{$\begin{array}{l}\text { Strategies of intervention } \\
\text { (see section "Problems } \\
\text { Associated With Strategies } \\
\text { of Intervention and } \\
\text { Relationships Between } \\
\text { Levels") }\end{array}$} & Norway & $\begin{array}{l}\text { RLCC in Nordland } \\
\text { Revision process of Carnivore Management } \\
\text { Plan } \\
\text { Controversy over the implementation of zoning }\end{array}$ & $\begin{array}{l}\text { Document analysis, participant observation in RLCC } \\
\text { meetings }(n=9) \\
\text { Interviews }(n=15) \\
\text { 1. What are the main controversies between the central and } \\
\text { the decentralized RLCC levels? } \\
\text { 2. How does clear zoning become a major issue of } \\
\text { contestation }\end{array}$ \\
\hline & Sweden & $\begin{array}{l}\text { WMD in Jämtland } \\
\text { Decentralization } \\
\text { Implementation of tolerance levels }\end{array}$ & $\begin{array}{l}\text { Document analysis and interviews }(n=23) \\
\text { Observation }(n=1) \\
\text { 1. In what ways has decentralization been implemented? } 2 . \\
\text { Which strategies of intervention have been applied to } \\
\text { integrate ways of knowing? }\end{array}$ \\
\hline \multirow[t]{2}{*}{$\begin{array}{l}\text { Knowledge spheres and } \\
\text { subject positions (see } \\
\text { section "Problems } \\
\text { Associated With Subject } \\
\text { Positions and Different } \\
\text { Knowledge Spheres") }\end{array}$} & Norway & $\begin{array}{l}\text { Local, regional and national authorities } \\
\text { Members and participants of the RLCC, } \\
\text { reindeer herders }\end{array}$ & $\begin{array}{l}\text { Participant observation at regional meetings }(n=9) \text {, } \\
\text { Interviews }(n=15) \text {. Participant observation at regional } \\
\text { meetings }(n=9) \\
\text { Interviews }(n=15) \\
\text { 1. Which ways of knowing and which actors are mobilized } \\
\text { in the management plan revision process? } \\
\text { 2. In what ways are environmental subjects generated in } \\
\text { the management process? }\end{array}$ \\
\hline & Sweden & $\begin{array}{l}\text { Regional and national authorities } \\
\text { Members of the WMDs }\end{array}$ & $\begin{array}{l}\text { Document analysis } \\
\text { Interviews ( } n=23 \text { ) } \\
\text { 1. Which ways of knowing and which actors are mobilized } \\
\text { in the management plan revision process? } \\
2 . \text { In what ways are environmental subjects generated in } \\
\text { the management process? }\end{array}$ \\
\hline
\end{tabular}

representatives. We followed the same procedure in regard to data collection and analysis here as in the RLCC meetings.

The study of the Swedish WMD was undertaken during 20152017 and included interviews with all the ordinary delegates and a selection of their substitutes $(n=15)$. We also included interviews with the CG, managers at the CAB of Jämtland $(n=8)$ and the Swedish Environmental Protection Agency (SEPA) $(n=2)$ and observed one meeting. The interviews lasted 1-2 h.

These case studies are set (Ragin, 1992) in specific times (2015-2018), places and institutional contexts, at the intersection of decentralized governance and national carnivore management in Norway and Sweden. In our analysis, we treat the two cases as separate processes, or "bounded cases" (Bartlett and Vavrus, 2017, p.46). However, there is also a certain level of interaction between these two cases, in the sense that they are part of networks of interaction among actors at different levels, as well as cross-border movements of animals. This interaction has not been analyzed.

\section{RESULTS}

In both Norway and Sweden, new approaches to large carnivore governance and management have emerged since 2000, each including some elements of collaborative governance or decentralization of authority (Sandström et al., 2009; SjölanderLindqvist et al., 2015; Hansson-Forman et al., 2018). We use the three aspects of environmentality to empirically analyze how different ways of knowing and thereby different knowledge spheres are favored or disfavored in these processes, which in turn may explain why the decentralization of natural resource management is contentious and contradictory, how and why it may create conflicts and result in controversies and unsettled outcomes.

\section{Problems Associated With Production of Rationalities of Rules and Conflicting Norms}

Most European countries have ratified nearly 40 environmental conventions and international agreements aimed at protecting the environment and preserving natural resources. Such conventions and agreements have to be translated and embedded in existing political and administrative systems, and the importance of different national policy contexts in these processes has been increasingly recognized (Hongslo et al., 2016; Hansson-Forman et al., 2018). The choice of institutional design, scope of change, and management mandate are all shaped by 
the interplay between international norms and rules and national policy contexts.

Both Norway and Sweden have signed the Convention on Biodiversity, $\mathrm{CBD}$, perhaps the most prominent and encompassing international environmental convention. The convention recognize the authority of indigenous peoples over their traditional knowledge art 8(j) \& 10(c), stating that national legislation shall respect, preserve and maintain knowledge and practices of indigenous and local communities since traditional lifestyles are relevant for the conservation and sustainable use of biodiversity. The convention is implemented through measures such as the Norwegian Nature Diversity Act (2009) and the framework of the 16 Environmental Quality Objectives that have been approved by the Swedish Parliament and constitute the backbone of Swedish environmental policy (Swedish Government Bill, 2009/10:155). In their respective Sixth National Report (6NR) to the CBD, and post-2010 National Biodiversity Strategy and Action Plan (NBSAP), both Norway and Sweden highlight the progress toward the protection of species (in particular large carnivores) although a number of measures remain to be achieved (see section "Problems Associated With Strategies of Intervention and Relationships Between Levels). When it comes to the implementation of targets $8(\mathrm{j})$ and 10(c) (United Nations, 2018a,b), the Norwegian report, besides international development aid, refers to the Finnmark Act of 2005; and the consultation procedure between the Norwegian state and the Sami parliament from 2005, but also the Nature Diversity Act of 2009 with its specific acknowledgment of Sami culture, as important steps toward achieving the objective of the convention. The Norwegian government also stressed the decentralized management of protected areas, where local communities including Sami representatives are involved, as an important route toward the implementation of the CBD (Neumann, 2017). The Swedish government reported the initiation of a national program on local and traditional knowledge related to the conservation and sustainable use of biological diversity (NAPTEK). The program was launched by the government in 2006 with the mission to work with issues regarding the documentation, maintaining and spreading of local and traditional knowledge, as well as to initiate research. In addition, the Swedish government also approved a new local administrative organization for the World Heritage Laponia, where the Sami have a large influence (Zachrisson, 2009; Reimerson, 2015; Holmgren et al., 2017). While comparing the two country reports, Norway has come much further in its implementation of the $\mathrm{CBD}$ with regard to both targets compared to Sweden. When it comes to articles $8(\mathrm{j})$ and $10(\mathrm{c})$, Norway focuses on land use rights and the co-management of protected areas, while Sweden focuses on mapping traditional knowledge. Noteworthy is that neither country explicitly mentions indigenous and traditional knowledge in relation to the conservation of species. These two aspects are continuously kept apart.

On a European level, the Council of Europe (1979) Convention on the Conservation of European Wildlife and Natural Habitats (hereafter Bern Convention) and 1992 Directive on the Conservation of Natural Habitats and of Wild Fauna and Flora (hereafter Habitats Directive) are important. The Bern Convention entered into force in Sweden and Norway in 1983 and 1986, respectively, and both countries have agreed to apply practices required to conserve wild species in need of "special protection" (Díaz et al., 2010). The Bern Convention obliges Contracting Parties to take measures to maintain populations of wild flora and fauna at appropriate levels according to ecological, scientific, and cultural criteria. In order to prevent serious damage to crops, livestock, forests, fisheries, water and other forms of property, Contracting Parties may make exceptions to restrict conservation provided that there is no other satisfactory solution and the exception will not be detrimental to the survival of the populations concerned. A document analysis suggests that, in particular, Norway's wolf policy is at odds with the country's obligations under the Bern Convention (Trouwborst et al., 2017). Norway has also been brought to court by nongovernmental organizations for failure to satisfy their duties under the Convention. Other studies show that the mitigating efforts prescribed under the Convention, are costly and lead to reduced animal welfare and lower income for farmers (Strand et al., 2019).

While the Bern Convention is particularly important from a Norwegian perspective, Sweden also has to follow the Habitats Directive, which requires Sweden as a Member State of the EU to take measures to reach or maintain FCS of natural habitats and wild plants and animals while also taking into account the economic, social, cultural and regional dimensions (European Commission, 1992). The concept of FCS is debated and remains contested - in particular with management measures used to mitigate conflicts or manage populations through, for example, protective or license hunting (Swedish Government Official Reports, 2012:22; Epstein, 2016; Christiernsson, 2018).

Our policy and document analysis of the implementation of the Bern Convention and the Habitats Directive in the two countries shows that the legal representation of large carnivores defined as a threatened species - has contributed to the framing of the species in single national units (e.g., the Norwegian wolves or Scandinavian wolves), followed by the use of new categories such as FCS and means of assessing the status in the individual countries. To be able to assess this status, our analysis shows that new categories of analysis have been invented, such as the specification of population targets and the monitoring of rejuvenating females. This has in turn generated the need for new methods for monitoring, and specific management strategies that have authorized certain experts (biologists and geneticists) to act upon these strategies. In this context, references to traditional knowledge are absent. In parallel to the implementation of the CBD, the Bern Convention and the Habitats Directive, Norway has been committed to safeguarding interests of the Sami people through the ratification of the International Labor Organization (ILO) Convention 169 on indigenous and tribal rights to land and water since 1991. With reference to this convention [(Norwegian Government Proposition Ot. prp. nr. 52., 20082009)], the Norwegian Nature Diversity Act (2009) specifies that the protection of biodiversity should ensure a basis for Sami culture and, further, that experienced-based knowledge resulting from traditional Sami use and interaction with nature should 
be considered in public decision-making. Furthermore, the Sami Parliament should be consulted in proposals for environmental protection that may affect Sami interests, and represented in governmental bodies, such as the RLCCs. However, the Norwegian government's interpretation and implementation of ILO Convention 169 is disputed, reflecting conflicting goals, priorities and norms (Johnsen et al., 2015). In relation to carnivore management and "clear zoning," which involves finding space for both carnivores and people with their grazing animals, our analysis shows that the Bern Convention is much more prominent in various arenas such as the RLCC than conventions protecting peoples' livelihoods. Sweden was an advocate for the Convention, but to date has not signed it. An official investigation in 1999 stated that Sweden already complied with most parts of the Convention, excluding Sami rights to lands (Swedish Government Official Reports, 1999:25). Thus, while ILO provides protection of Sami culture and traditional ecological knowledge in Norway, in Sweden such protection formally rests on CBD article $8(\mathrm{j})$ and $10(\mathrm{c})$.

In Norway, the MCE is responsible for overseeing the implementation of both the CBD and Bern Convention, with delegated authority to the NEA. The Ministry of Local Government and Modernization is responsible for implementing ILO Convention 169 and reporting on progress, while the Ministry of Agriculture has overall responsibility for reindeer herding. In Sweden, the government has given SEPA overall responsibility for implementing the $\mathrm{CBD}$, Bern Convention and Habitats Directive. However, due to the decentralized design of large carnivore governance, the CABs and Sami Parliament also have some responsibility for their implementation. The Sami parliament has a central role in safeguarding interests of the Sami people, including reindeer herders' land and water requirements. Our analysis of the international commitments of Norway and Sweden to safeguard biodiversity conservation while at the same time protect human and indigenous rights shows how conflicting national-level obligations and commitments to international conventions are decentralized. This leaves the regional-level decision-makers with the dilemma where they need to be attentive toward the needs and values of the different levels. Consequentially, this means that they run the risk of being overruled by the central level. Our analysis further shows that there is a need to clarify the concrete local implications of different - and locally contradictive - legal and normative rules. This process has started, with a Swedish verdict from 2020 stating that ILO 169 gives precedence to Sami rights in one concrete case concerning hunting and fishing rights. The further implications of this verdict both in Sweden and Norway remain to be seen. In sum, the pattern that emerges is that the chosen approaches in the two countries have been characterized by sectorization, where different authorities are responsible for the implementation of different international agreements. Thus, the production of rationalities of rules is complicated by fragmented institutional implementation. None of the policy processes and subsequently responsible authorities at the national level engages with socio-ecological systems holistically. Hence, the document analysis shows how the large carnivore policy sector values only one way of knowing, i.e., the one grounded in natural science that focuses on statistical measurement, modeling and data analysis based on ecological theory. In the environmental sector, other ways of understanding and engaging with the world are consequently subordinated. On the other hand, the implementation of the guidelines for the safeguarding of indigenous rights is also one-sided since these guidelines only highlight traditional ecological knowledge and not the need for integrating various ways of knowing.

\section{Problems Associated With Strategies of Intervention and Relationships Between Levels}

In both our cases, key elements of strategies of intervention (the second aspect of the environmentality framework), include decentralized governance - implemented with the intention to increase legitimacy and reduce conflicts - and associated processes and controversies regarding management solutions that are considered acceptable or appropriate. Since the two countries share large carnivore populations, they have also decided to develop a common monitoring program (Rovdata), in which carnivore populations are estimated by counting rejuvenating females of each species (ynglinger in Norway and föryngringar in Sweden) and in accordance with a strict set of rules. The goal of this program is to standardize, systematize and coordinate the work on carnivores (Andersen et al., 2003; Risvoll and Kaarhus, forthcoming). Problems associated with the strategies of intervention in Norway and Sweden are outlined in the following sections, first describing the two cases in focus, Nordland and Jämtland, and second an analysis of the generation of "environmental subjects" at levels where different ways of knowing and knowledge spheres interact.

\section{Nordland, Norway}

Currently, large carnivore governance and management in Norway draws on the Norwegian Parliament's Document 15 (Stortinget. 2003-2004., 2003), the Parliament's treatment of this document and CAs issued in 2004, 2011 and 2016 intended to secure survival of large carnivores and persistence of their habitats (Rovbase, 2019).

An important element of the 2011 CA was delegation of management authority for large carnivores from the central government to representative RLCCs, which are formally appointed by the MCE. The RLCCs' mandate is framed by the CA and the Carnivore Regulation (Norwegian Carnivore Regulation, 2005), which stipulates that the "management should be differentiated so that different interests are emphasized differently in different areas and for different carnivores," and further that the management should enable predictability and local participation. Further, the RLCCs have a mandate to take decisions regarding licensed hunting, quota hunting, and protective hunting as long as the population goals are reached. As a government-appointed committee, the RLCC in Nordland, consisting of four regionally elected politicians and two members nominated by the Sami Parliament, 
has to comply with national carnivore policies, and can be instructed by the NEA. The final authority to pass regional management plans remains at the national level. The population goals for large carnivores in Nordland are: one rejuvenating bear (female with cubs), 10 rejuvenating lynx (female with kittens), and 10 rejuvenating wolverines (female with pups). The allocation of population goals for each carnivore species in the eight Norwegian regions vary greatly (Table 2).

The RLCCs are responsible for developing and implementing management plans, which according to the Carnivore Regulation should establish geographically differentiated management through zoning (called "clear zoning" in government documents). The goal is to reduce spatial overlap between populations of large carnivores (bear, lynx, wolverine, wolf) and domestic livestock, such as reindeer and sheep (e.g., Krange et al., 2016). Large carnivores are prioritized in certain defined areas, while grazing animals are prioritized in others. There has been an ongoing controversy in the RLCC meetings about the size of these areas. Some participants are worried that choosing too large areas for predators will affect their pasture access too much, while others are worried that too small predator areas will make too many restrictions on local level management in regard to culling and hunting. The regional plans have to comply with overall population goals, set by the CA with reference to the Bern Convention, and defined in terms of "rejuvenating females" of each species (Stortinget 2010-2011., 2010). Moreover, the RLCCs have to cooperate with municipalities and other organizations when developing the plans.

The first management plan in Nordland was passed by the RLCC in 2011. This plan was criticized by government officials for being too fragmented, and excessively favoring grazing areas over carnivores' habitat needs (Risvoll, 2015). In 2015, the MCE and MAF asked the Nordland RLCC to revise their management plan, with the aim of conducting "clearer zoning" for achieving more predictable management and to reduce the high levels of conflict as a result of great livestock losses (Risvoll and Kaarhus, forthcoming).

Starting in 2015, the revision of the management plan uncovered conflicting views and priorities, not only among different stakeholders and interest groups, but also between the RLCC and CG. The revision process created a heated debate regionally, and during a public consultation the RLCC received around 90 written statements from local and regional stakeholders. Drawing on this wide array of material and continuous discussions within the Committee, the RLCC passed a revised management plan, and sent it to the NEA for final approval in January 2017. Later that year, the NEA rejected the revised plan, arguing that it did not comply with national policy and the principle of "clear zoning." "The RLCC received the following response to its revised plan in a letter from the NEA: The Agency's view is that this draft is unsuited to comply with the national population goals set for the Region... [and it] will most likely boost conflicts... The draft plan is therefore not suitable as an instrument for carnivore management in the Region." Thus, the NEA returned the plan to the RLCC with instructions for improving it. While the NEA acknowledged in writing the inherent challenges in using geographical differentiation in Nordland due to geographical characteristics but also the scale of both pastoralism and carnivore populations, they still insisted on "clearer zoning." The RLCC representatives spent much time in their board meeting discussing back and forth how to deal with very difficult issues. There is much frustration locally because of large losses to predators. Hunting to cull animals when losses to predators are high locally, have however been turned down by the government due to population goals not being met for Nordland as a whole. A second revision by the RLCC resulted in few changes, and Nordland RLCC resubmitted the management plan to the NEA in spring 2018. Then the MCE overruled the plan, arguing that the zones neglected "the carnivores' biology," and hence was unsuited to comply with the national population goals, and likely to boost conflicts at national level. The MCE also rejected the RLCC's request to discuss the nationally decided population goals, which the government emphasized is a "strictly political" measure, and beyond the RLCC's mandate. Thus, localand regional-level actors have been left with very restricted options in the decentralized management system, and some (such as interest organizations and local authorities) have voiced their concerns through various channels and arenas in efforts to increase their influence at other governance levels.

\section{Jämtland, Sweden}

The first coherent large carnivore policy in Sweden, implemented in 2000, included some elements of decentralization, e.g., the establishment of RLCCs, which later were discontinued because they failed in legitimacy (Swedish Government Bill, 2008/09:210). A new policy was adopted in 2010, and further amended in 2013, replacing the advisory RLCCs with WMDs, one in each county, to further increase regional and local influence over large carnivore management. In parallel to the regional authority, three councils, agglomerating the CGs, were established to coordinate and divide the numbers of large carnivore species between the counties in three regions (northern, middle and southern).

The WMD in each county is led by the CG and includes representatives of: political parties; forestry, local business, outdoor recreation, hunting, nature conservation, agriculture, reindeer herding, fishery, and mountain farming interests; and the Sami Parliament where appropriate (Swedish Code of Statutes, 2009). The WMD has a formal mandate to: decide overall guidelines and management plans for large carnivores; license hunting and protective hunting within the county if they cause serious damage (especially to crops, livestock, forest, fishing, water and other types of property); and provide grants and compensation according to the Wildlife Injuries Ordinance (Swedish Code of Statutes, 2001, 2010). In accordance with the Bern Convention and Habitats Directive, licensed and protective hunting may only be granted if there is no other suitable solution and it does not make it difficult to maintain FCS.

Regarding numbers of animals, the WMDs only assume an advisory role in recommending minimum and interim levels of county carnivore populations. How many large carnivores there should be in each county and region is decided by the SEPA, based on national reference values adopted by the Swedish Parliament in accordance with international conventions and 
TABLE 2 | Population goals for large carnivores in the eight Norwegian regions ${ }^{1}$.

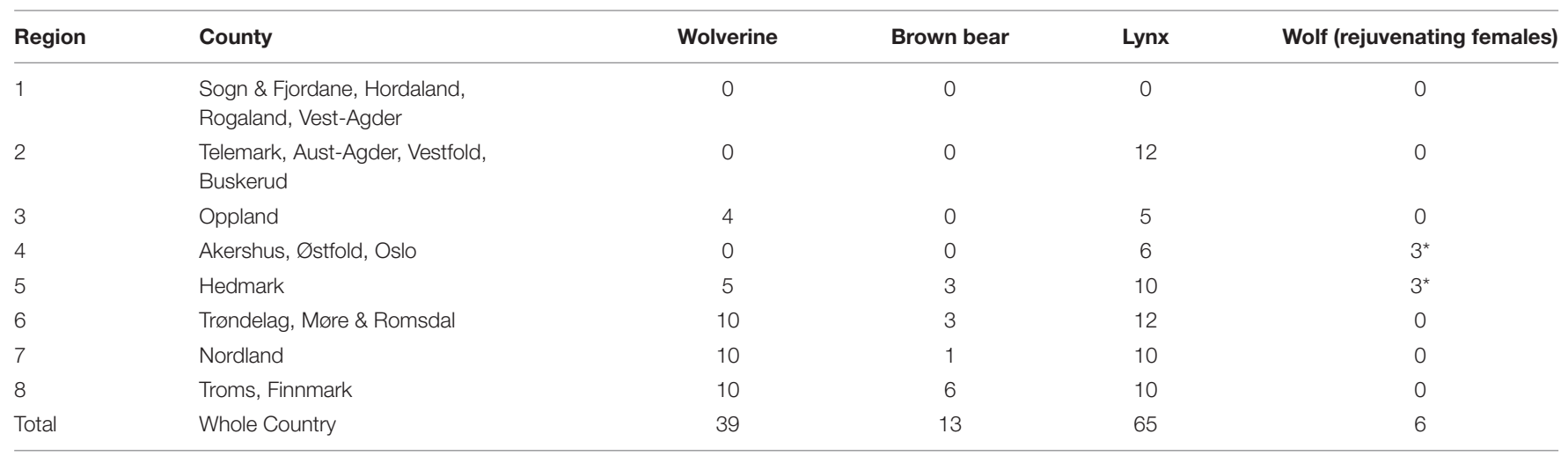

*Regions 4 and 5 have joint responsibility for three rejuvenating females ("ynglinger") of wolves.

${ }^{1}$ These numbers refer to the minimum levels and is based on rejuvenating females. Norway has currently identified 100 wolves via DNA and Norway see these wolves as part of a Scandinavian wolf population (i.e., Norway and Sweden), and the total estimated population is approx. 430 wolves. As regards the brown bear there are approx. 150 individuals in Norway and the number is increasing.

TABLE 3 | Minimum levels of large carnivores (=FCS) in the NLCR in Sweden (numbers identified through inventories 2017/2018 in brackets).

\begin{tabular}{lcccc}
\hline County & Wolverine & Brown bear & Lynx & Wolf \\
\hline Norrbotten & $46(50)$ & $330(506)$ & $17(14)$ & 0 \\
Västerbotten & $23(23)$ & $110(362)$ & $13.5(33)$ & $0(3)$ \\
Jämtland & $23.5(66)$ & $360\left(117^{\star}\right)$ & $20(48)$ & $0(16)$ \\
Västernorrland & $1(2)$ & 100 & $16(21)$ & $0(7)$ \\
Total in the NLCR & $93,5(141)$ & $90(2047)$ & $66,5(116)$ & $0(26)$ \\
\hline
\end{tabular}

For wolverine and lynx, figures are presented for rejuvenating females and bear the total number of animals (Länsstyrelserna, 2018).

*Identified number of brown bears in Jämtland and Västernorrland (Länsstyrelserna, 2018).

the Habitats Directive. In the NLCR, which largely corresponds to the reindeer husbandry area, the county of Jämtland should have at least 23.5 and 20 reproducing wolverines and lynx, respectively, and 360 brown bears (Table 3; Länsstyrelserna, 2018). If numbers of carnivores fall below designated minimum levels, the power to take protective and licensed hunting decisions is re-centralized to the SEPA.

Until 2013, there were no focused intervention strategies for reducing the losses of reindeer husbandry to large carnivores. The needs for protection were only stated in general terms and lacked concrete policy instruments. This contributed to political and administrative ambiguity, causing difficulties for the management authorities as well as reindeer herders. It often led to more account being taken of the numbers of large carnivores recorded in the monitoring program than of Sami reindeer herders' needs for protection, who thus faced unpredictable situations. As stated in a report by the Swedish Environmental Protection Agency [SEPA] (2013) the Swedish large carnivore policy is not balanced in relation to reindeer husbandry, as it is based on actual, binding numbers for conservation interests, but unclear grounds for safeguarding Sami property.

To maintain sustainable reindeer husbandry in Sweden while meeting FCS goals for the large carnivores, new management measures were introduced in 2013 (Swedish Environmental
Protection Agency [SEPA], 2013). One was adoption of a "tolerance level" (the maximum acceptable level of predatorrelated losses during a year, defined as a percentage of the number of reindeer owned by a reindeer herding community). The other was an obligation for the relevant CABs to work together with the reindeer herding communities to keep losses of reindeer due to large carnivores at an acceptable level (Swedish Environmental Protection Agency [SEPA], 2013). In effect, this meant the introduction of a $10 \%$ tolerated damage threshold, i.e., $10 \%$ of stock losses, and possible approval of targeted removal if the threshold is exceeded.

In Jämtland, where losses of reindeer due to large carnivore predation have reportedly varied between $10-40 \%$ in the 12 reindeer herding districts, the $C A B$ has worked together with the districts to set up management plans to implement the new policy instrument of tolerance levels (Decision NV-0722115). Since Jämtland hosts approximately $35 \%$ of the wolverine population in Sweden, the management plans primarily targeted wolverines in areas where they were causing most trouble, not only by killing animals but also by making reindeer avoiding grazing certain areas because of the abundance of the carnivore. Thus, the reindeer herders could not effectively use the already shrinking pastures available to them. As a result of the consultation process with the reindeer herding districts in 2014-2015, the CAB and WMD decided in September 2015 to lethally remove 19 wolverines through protective hunting from the reindeer husbandry area. However, one of the nature conservation organizations represented in the WMD appealed against the decision, primarily because formal prerequisites for protective hunting had not been met. The organization argued that the $\mathrm{CAB}$ had not been provided enough evidence that losses of the reindeer herding districts amounted to $10-40 \%$, that there was no other suitable solution to the problem, or that the decision would not jeopardize the FCS of the species. In October 2015, the SEPA overruled the CAB's decision on similar grounds, i.e., the evidence presented by the $C A B$ was considered insufficient, in terms of both the extent of the damage and estimated effect of lethal removal of the carnivore. The decision to stop the 
protective hunting, which undermined possibilities to implement the new policy based on tolerance have been heavily criticized by the involved reindeer herding districts, the association for reindeer husbandry in Sweden, and the CG. The CAB have, due to their attempts to implement the tolerance policy and lower the number of wolverines, been deprived of the right to make decisions on protective hunting.

\section{Problems Associated With Subject Positions and Different Knowledge Spheres}

Despite both countries having, in principle, decentralized large carnivore management, our cases show that the intentions to devolve decision making to regional and local levels are obstructed by central agencies. In the following analysis of the third aspect of environmentality, we focus on how knowledge spheres are mobilized to contest the dominant management approaches in the two cases, and how they are, or are not, reproduced and legitimized in policies, regulations and management interventions.

\section{Mismatch Between Ways of Knowing and the Urge for Holism in Nordland, Norway}

The reindeer herders interviewed in Nordland strongly felt that the knowledge base of national carnivore management does not reflect the reality they experience on the ground. One herder noted that, "The official numbers of predators do often not reflect what we see in the mountains. We see predators and their tracks, but it is often very difficult for us to fulfill the government's strict methods for predator documentation due for example icy snow conditions or winds that cover the tracks with snow." The local complexities of topography, geography, multiple carnivore populations and carnivores' movements, as well as the livestock-carnivore interactions, were often voiced by members of the RLCC in meetings and by herders at hearings that took place during the revision process. They considered the zoning requirements particularly challenging due to geographical constraints that left few options for avoiding overlap between carnivores and grazing animals. The CG and NEA acknowledged these challenges, but also emphasized that the RLCC could not deviate from their obligation to meet national population goals for carnivores through clear zoning.

Deciding zones is perceived by some RLCC members as a nearly impossible task, and difficult to relate to as they know that any borders they draw will be recognized and respected by neither carnivores nor their reindeer and sheep. There is a fear among local-level actors that prioritizing areas for the large carnivores that overlap with existing grazing land will gradually squeeze out the pastoralists' possibilities to cope in these areas. Consequences of living in a carnivore zone include difficulties in getting culling permission when needed and loans for investing in required equipment and infrastructure. These concerns were highlighted by various actors attending RLCC meetings, and representatives of the Sami Parliament, who have abundant knowledge about herding in the region. Nevertheless, national authorities are pushing the RLCC to pass a management plan that gives little scope for maneuver outside the frames of the national policy with its specified population goals.

When discussing the revision of the management plan, representatives in the RLCC had somewhat diverging views on optimal ways to deal with the required area differentiation, and a need to go beyond deciding upon zoning was frequently discussed, although this was beyond their mandate. The committee members showed strong commitment to their perceived downward accountability, and awareness of local concerns regarding population goals and the consequences of zoning for local communities, particularly for the pastoral industries. These concerns were voiced in the hearings and discussions during RLCC meetings. The "bear zone" has proved to be particularly difficult for the RLCC to reach decisions, as currently existing alternatives, based on biological data on bear habitats, will overlap with either calving land for reindeer or important grazing land for both reindeer and sheep. Local actors, engaging in discussions in RLCC meetings, through public hearings and in local media, have argued that more knowledge must be obtained on social and cultural impacts of larger bear populations co-existing with pastoralists and local communities in Nordland. One RLCC representative stated: "We need to show we protest against stated policies on the population goal and zoning of bears in a region with both reindeer herding and sheep farming like we have here, and I have great difficulty in signing a document with a bear zone in this region when I know the potential consequences this can have for the pastoral industries." Another voiced concern as follows: "Having bears in calving lands for reindeer will mean the end to reindeer husbandry in these areas." The need for more knowledge on social impacts of the proposed bear zones has been discussed numerous times in the RLCC meetings, and while the leader of the RLCC opted for an independent impact assessment, both the national and regional governments have responded that they see the existing knowledge base as sufficient.

The goals for carnivore populations (rejuvenating females) stated in government documents form the basis for zoning and management. The methods for registering and documenting carnivore population numbers are perceived by the government as being among the best in the world (Andersen et al., 2003). However, the local pastoralists perceive a clear mismatch between numbers of carnivores registered through the formal methods, and their experiences of carnivore populations in the landscape. Interviewed herders point to a need for a more holistic outlook, and the importance of understanding the topography and climatic conditions, as well as reindeercarnivore interactions. The space to navigate in decentralized large carnivore management is actually perceived as marginal by different interest groups. Members of the RLCC and actors involved in the management plan revision process have highlighted difficulties in reaching the national level to get their voice heard. Participants in the audience during RLCC meetings noted that: "Decentralization only counts as long as the RLCC do as they're told" and "The management plan is our (local level) most important document, and it's not good if the national government doesn't trust us to test out what has been decided for our management." 
Our interviews show that local actors involved in or connected to the decentralized management of large carnivores are searching for other avenues to reach the decision-makers. The Norwegian Union for Outfield Municipalities is one such arena that can assist municipalities in cases related to matters concerning, for example, large carnivores. While actors from the pastoral sectors always attend RLCC meetings, environmental organizations rarely do. They see them as being too biased toward livestock grazing and pastoralists' interests. Instead, they seek to exert influence through other arenas, such as the media, or submissions to hearings in national-level planning processes (Risvoll et al., 2016).

\section{Knowledge Hierarchies and Lock-in Effects in Jämtland, Sweden}

Concomitantly with implementation of the large carnivore policy, reindeer herders face steadily increasing damage to their herds, making it increasingly difficult to make a living from reindeer husbandry. Their livelihood has to a large extent changed from regular herding to preventive work, looking for reindeer killed by carnivores and finding ways to prevent additional damage by large carnivores. Even if their interests are expressed in the governance system, their representatives perceive that their knowledge, based on lived experience through many generations, is marginalized, sometimes to the point that it is completely inconspicuous. As one noted: "Given that the reindeer herding industry actually supplies half of Sweden's large carnivores with food, we've been given too little space in the WMD in terms of knowledge. We've had full days with information about each large carnivore, and we've been thoroughly informed about the regulations, but when it comes to the issue of reindeers and impacts, we've been given an hour or so."

This marginalization of experiences and knowledge clearly limits possibilities to the collaborative discovery of common interests, concerns and values, and to open and expand sources of information to define a shared meaning and understanding of common concepts. Hence, even if the delegates have been offered education, the focus has been on the large carnivores and their role in nature, their actual numbers and how it relates to the concept of FCS, despite the expressed objective of the large carnivore policy to also acknowledge the needs for those having to co-exist with large carnivores.

The decentralization of the governance and management of large carnivores, and the decision to implement a $10 \%$ tolerated damage threshold for reindeer husbandry, seem to have affected the relationships both between the $\mathrm{CAB}$ and the pastoralists, and between regional- and national-level actors. Our interviews with the WMD delegates show that in recent years the CAB has become more responsive to the local level, which reflects the need to balance international commitments with local realities.

As described above, the $\mathrm{CAB}$ worked closely with the reindeer herding districts for several years to develop intensity maps to eventually implement the $10 \%$ tolerated damage threshold level for reindeer herding. This threshold laid the ground for the decision to lethally remove 19 wolverines through protective hunting from the reindeer husbandry area. However, the decision was overruled by the SEPA, which referred to insufficient scientific evidence since the $\mathrm{CAB}$ had not been able to justify this removal in terms of any of the three criteria that should have been met. With support by research (e.g., Aronsson and Persson, 2017), the CAB considered that removal of the wolverines would not jeopardize their FCS. However, the SEPA argued that any lethal removal must take into consideration not only the county's population target, but also the potential needs in the other 3 counties in the Northern Large Carnivore Region, which in turn are related to the national objectives (see Table 3 ). This set a precedent that greatly limited local discretion to make decisions regarding lethal removal and surprised many delegates in the WMD. As one of them said: "I expected Jämtland County to be in charge of its own situation. I had not understood this, it's like a hostage situation in the NLCR." Finally, we read from the decision to overrule the culling of the wolverines that the CAB (and the WMD) had not been able to present alternative solutions. In response, the $\mathrm{CAB}$ referred that "the appeal's suggestion that other solutions might be suitable is obviously unrealistic. It is not relevant to describe in decision after decision solutions that are irrelevant for reindeer husbandry to cope with large carnivore problems. These are simply not appropriate." The appeal process reflects an established knowledge hierarchy, where technological and scientifically constructed knowledge consistently trumps solutions based on experience in a local context. As one of the interviewees said: "I feel that scientific results are considered valid knowledge, while traditional knowledge has low status in Swedish society." This tendency to prioritize a certain kind of knowledge makes it difficult to meet the intentions to continuously build knowledge and understanding of different perspectives, as expressed in meetings and documents preceding the decision on tolerance levels (Swedish Environmental Protection Agency [SEPA], 2013).

\section{DISCUSSION}

In our two case studies we have seen how decentralization is understood as a tool that could help reconcile local concerns with normative conservation commitments without compromising either resource-based livelihoods or the viability of wildlife populations. However, due to a multitude of partly divergent international norms, large carnivore governance and management become fragmented when responsibility for implementing different norms is divided between ministries (as in the Norwegian case), and between national authorities and between government levels (both cases). In large carnivore conservation overall, responsibility for environmental commitments has been delegated to the ministries and/or national agencies, while responsibility for implementing centrally defined policy goals, through decentralization, has been assigned to bodies at regional levels. Following Manor (1999), typology such decentralization of wildlife and large carnivore management can best be described as deconcentrated or administrative decentralization. This means that in both cases the regional bodies remain upwardly accountable, although some power and resources have been transferred to lower levels. However, in both cases the local and regional representatives 
see themselves also as downwardly accountable, with the task to balance between different aspects in order to achieve dual goals of the policy. Hence, decision-making becomes compromised by tensions and conflicts between different principles, aims and demands. In the conflicts between downward and upward accountability, national-level agencies tend to prioritize certain normative commitments. Thus, while international conventions and national policies promote some form of decentralization, as a means to establish environmental collaborative governance at regional or local levels and support sustainability, their implementation emerges as a process of "collective brokering" (Wenger, 1998) over values and ends, attributions of meaning, normativity and clashes regarding rationales of knowledge but also how rules should be interpreted. Another way to describe this situation is that decentralization forms a locus of power where, as we have seen in both cases, national-level agents largely set what is to be considered valid, normalizing particular ideas and concepts, and dismissing certain problem descriptions. This inevitably leads to dilemmas for the decentralized bodies seeking to fulfill their mandates.

While governance in both countries is founded on - in principle - decentralized management authority at the regional level, our analysis of the Norwegian case shows that local actors struggle to have their views acknowledged and counted as valid knowledge when interacting with agencies in upper governance levels. Similarly, in the Swedish case, local pastoralist voices in the WMDs, supported by the $\mathrm{CAB}$ as well as other stakeholder interests, have encountered problems when striving to implement tolerance levels. In both cases, the regional level arrangements provide arenas for continuous increases in mutual knowledge and understanding of all the represented interests' perspectives. However, this is subordinate to a discourse prioritizing scientifically quality-assured knowledge, even if such knowledge should officially be used together with "the reindeer herders" traditional knowledge regarding both large carnivores and reindeers" (Swedish Environmental Protection Agency [SEPA], 2015; cf. Eira and Sara, 2017). The prevalent knowledge hierarchy may arise at least partly because the two countries' central agencies simply lack knowledge and insights regarding conditions the reindeer herders and their livestock face in areas populated with large carnivores. However, it seems more likely that national-level actors can easily adopt an obstructive stance that undermines decentralized governance and management of large carnivores. This is because they are far from the socio-cultural and geographic contexts of the issues, and they do not have to deal with them on a daily face-toface basis. The resulting limitation of agency at the regional level exacerbates difficulties in meeting its delegated obligations to implement the dual objectives of the large carnivore policy in practice - i.e., safeguarding both carnivore populations and interests of reindeer husbandry. The lack of discretionary power has also contributed to, or exacerbated, a loss of trust among particular pastoral interests. In contrast, this course of actions seems to, in the Swedish case, have strengthened subject positions of the conservation interests in the WMD when they have chosen to exert influence through judicial arguments. In Norway, the conservation interests have similarly exerted influence through other arenas, such as the media, or submissions to hearings in national-level planning processes (Risvoll et al., 2016).

This discrepancy clearly affects possibilities for the regional level (and the RLCC and WMD) to develop what Emerson and Nabatchi (2015) refer to as a "common theory of change," that is, assumptions about the process through which change will occur (p. 63). However, even if members of the decentralized bodies do not have shared goals, they may still be able to discover common interests, concerns and values to achieve agreed policies and management goals. Here, leadership plays a critical role when the stakeholders, or members of the decentralized body, do not fully share ownership of the process and its outcomes (Cinque, 2008; Sjölander-Lindqvist et al., 2015). While the two decentralized management models potentially enable inclusion of different knowledge spheres, the national-level bodies in particular, have yet to acknowledge the challenges of knowledge being dismissed or marginalized across governance levels and scales. Thus, the decentralized governance bodies are stripped of abilities to consider knowledge that is not scientifically approved. Consequently, both the RLCC and WMD lack power over key issues in carnivore management.

Over the years, large carnivore management in both countries has largely focused on developing evidence-based monitoring of wolves, brown bears, lynx and wolverines, but there is a lack of equivalent monitoring measures regarding predation of reindeer. This creates uncertainties for the reindeer herders, who to a great extent rely on local and experience-based knowledge of carnivore behavior and carnivore-reindeer-landscape interactions. Even if decentralization has been suggested to be "potentially more responsive to local ecological conditions and more adaptive to highly variable northern ecosystems" (Nadasdy, 2005, p.216), we have found clear evidence of a knowledge hierarchy in both Norwegian and Swedish large carnivore management. Nadasdy (2005) gauged bureaucratization as an important obstacle hindering integration of traditionally, indigenously, and locally based knowledge regimes (cf. Scott, 1998; Failing et al., 2007). However, we argue that to avoid failure of decentralization, there is a need to move away from the siloed politics and to expand capacities of the decentralized bodies and the policies to reduce the tendencies of central agencies to constrain or even take over decentralization efforts (Ribot et al., 2006). The central agencies seem to resist the transfer of sufficient appropriate powers to lower levels, and this tendency seems to be exacerbated by weak institutional arrangements (cf. Falleth and Hovik, 2009) and distrust of lower level actors' abilities (or willingness) to comply with policy (cf. Cinque, 2008, 2015). If the governance models are not designed appropriately, the concerned actors are left with restricted options to influence and push their objectives (e.g., Risvoll et al., 2016). Hence, they may consider stepping out of the formal governance arena and seek to exert influence at different governance levels that are closer to final decisionmaking levels.

Both the biological and the cultural environment can restrict and sometimes hinder goals and projects set by society, but overarching plans and policies can also, the other way around, affect the capability of local communities to produce and uphold their means for identity formation, value production, and 
sustenance (Appadurai, 1995). Thus, it is not surprising that the described conflicts present challenges that need to be resolved if the decentralization process is to be successful. A potential alternative approach is adaptive management, which builds on capacities of actors or systems to adapt to actual or anticipated change (Armitage and Plummer, 2010) and develops as part of a social process involving multiple actors. This is reflected in the Norwegian case, where local actors request the possibility to apply the CMP in practice. It is also reflected in the Swedish case, where the $C A B$ has worked together with the districts to establish plans to implement the new policy instrument on tolerance levels, and the WMD has discussed the issue and taken decisions regarding lethal removal of wolverines. However, the central agencies have dismissed these efforts at lower levels in the management system and relied instead on their own perceptions of the problems and solutions they regard as acceptable, referring to the established knowledge hierarchy in the environmental sector. In Norway, CMPs are being either marginalized or taken over by the national government, and in Sweden, the SEPA overruled the decision to remove 19 wolverines and undermined possibilities of the regional agency to implement the new policy on tolerance levels. While Jämtland had reached its population goals, fellow counties in the Northern Large Carnivore Area had not. This created a lock-in situation for Jämtland who had to assume a subordinate position, which meant they could not implement the new policy on tolerance levels. However, 3 years later, the FCS of wolverines have been achieved (600 rejuvenating wolverines) in the Northern Large Carnivore Area. This meant that the SEPA could open up the possibility to reduce the concentration of wolverines in Jämtland where the population is at its densest and without jeopardizing the FCS of the wolverine. In contrast to the decision made by the $C A B$ in 2016, which was based on a combination of scientific evidence and traditional ecological knowledge, the decision by the SEPA in 2019 was based on monitoring data, once again clearly unveiling the hierarchy between different ways of knowing.

\section{CONCLUSION}

By comparing two cases in two countries, we have analyzed how international norms have been incorporated into the respective large carnivore polices, and how these policies laid the foundation for strategies aimed at decentralizing management and decision-making. We show how the implementation of the strategies have been far from easy. Rather, this study shows that international conventions aimed at the preservation, protection and maintenance of biodiversity as well as international conventions regarding the safeguarding of traditional/indigenous knowledge legitimize partly incompatible ways of knowing, which in turn gives rise to conflicts and difficulties in their implementation. Since the different conventions have different intentions, they are to some extent contradictory. The contradictions are enhanced due to how these conventions are translated into siloed national policies by creating multifaceted goals (the first aspect of the environmentality framework), which in turn causes conflict between levels (the second aspect of the environmentality framework). In our two cases, we find that in the design of the institutions in both Norway and Sweden, the decision-making power has been transferred to bodies that include political and Sami representatives (RLCCs in Norway), or representatives of political parties and members of selected interest organizations (WMDs in Sweden). However, they have limited options to make decisions and both face the dilemma of having devolved responsibilities without real decision-making power. This dilemma is accentuated through different actors operating with reference to distinct knowledge spheres (science- or local experience-based; the third aspect of the environmentality framework). There is further a lack of mutual acceptance of the validity and reliability of the information about large carnivores presented by scientists and, in our cases, reindeer herders, respectively. When the regional bodies seek to make decisions, including local experience-based knowledge, they find themselves overruled by the central sector agencies. As a result, both the RLCCs and WMDs find that they are expected to work as extensions of the central state, and what remains is upward accountability, where only arguments within the science-based knowledge sphere are accepted as valid at central levels.

Our empirical results support the proposition that the integration of different ways of knowing is challenging. Even if there is widespread, even global, support for democratic decentralization as a key component of good governance, our results show a fragmented situation. Understanding how a multitude of international norms plays out and obstructs just and equal management in a local context, provides insights that will be beneficial to the ongoing debate on what is needed to encourage consensual and potentially more holistic solutions, and on how to provide empowerment in political processes and policy implementation. The lessons drawn from the comparison carried out using an environmentality framework contribute to an understanding of the quandaries associated with decentralization - not only within the field of large carnivore management. There is a need to level out the imbalance between different knowledge spheres and between downward and upward accountability to avoid increased distrust for both management and politics. What is obvious is that the accountability dimension needs to be resolved in order to balance the multifaceted goals of policy and the current knowledge hierarchy also needs to be leveled out. On one level it may be difficult to oversee the FCS, but if we turn to the implementation level we find it urgent to increase the understanding and acknowledgment of local knowledge. It is also important to allow for regional adaptation due to socio-ecological variation. To approve of this, and in line with the different international commitments, the discretionary and necessary power for the regional level, need to be considered in order to safeguard both carnivore populations and the interests of pastoralism. Process ownership is vital to avoid upper level dismissal and/or marginalization of local knowledge.

\section{DATA AVAILABILITY STATEMENT}

The datasets generated for this study will not be made publicly available. The dataset contains personal information, and the informants were granted anonymity. Requests to access the datasets should be directed to the corresponding author. 


\section{ETHICS STATEMENT}

Both case studies have been implemented following the European Code of Conduct for Research Integrity; including the principles of reliability, honesty, respect, and accountability. Ethical review and approval was not required for the Swedish case study in accordance with the local legislation and institutional requirements. The Norwegian Centre for Research Data made an ethical review and approved the project on behalf of the Nordland Research Institute. Written informed consent for participation was not required for this study in accordance with the national legislation and the institutional requirements.

\section{AUTHOR CONTRIBUTIONS}

AS-L, AL, CR, CS, and RK: conception and design of study, analysis of data, drafting the manuscript, revising the manuscript critically for important intellectual content, and approval of the

\section{REFERENCES}

Agrawal, A. (1995). Dismantling the divide between indigenous and western knowledge. Dev. Change 26, 413-439. doi: 10.1111/j.1467-7660.1995.tb00560.x Agrawal, A. (2005). Environmentality: Technologies of Government and the Making of Subjects. London: Duke University Press.

Agrawal, A., and Chatre, A. (2006). Explaining success on the commons: community forest governance in the indian Himalayas. World Dev. 34, 149166. doi: 10.1016/j.worlddev.2005.07.013

Allard, C. (2011). The Nordic countries' law on Sámi territorial rights. Arct. Rev. Law Polit. 3, 159-183.

Allard, C. (2015). Renskötselsrett i Nordisk Belysning. Göteborg: Makadam Förlag.

Andersen, R., Linnell, J., and Hustad, H. (2003). Rovvilt Og Samfunn i Norge. En Veileder til Sameksistens $i$ det 21. århundre. Temahefte 22. Trondheim: NINA.

Appadurai, A. (1995). "The production of locality," in Counterwork, ed. R. Fardon (London: Routledge), 204-225.

Armitage, D., and Plummer, R. (eds) (2010). Adaptive Capacity and Environmental Governance. Heidelberg: Springer.

Aronsson, M., and Persson, J. (2017). Mismatch between goals and the scale of actions constrains adaptive carnivore management: the case of the wolverine in Sweden. Anim. Conserv. 20, 261-269. doi: 10.1111/acv.12310

Bartlett, L., and Vavrus, F. (2017). Rethinking Case Study Research: A Comparative Approach. New York, NY: Routledge.

Becker, H. S. (1992). "Cases, causes, conjunctures, stories, and imagery," in What is A Case?, eds C. C. Ragin and H. S. Becker (Cambridge: Cambridge University Press), 205-216.

Berkes, F. (2010). Devolution of environment and resources governance: trends and future. Environ. Conserv. 37, 489-500. doi: 10.1017/S037689291000072X

Bäckstrand, K., and Lövbrand, E. (2006). Planting trees to mitigate climate change: contested discourses of ecological modernization, green governmentality and civic environmentalism. Glob. Environ. Polit. 6, 50-75. doi: 10.1162/glep.2006. 6.1 .50

Christiernsson, A. (2018). Managing Strictly Protected Species With Favourable Conservation Status: The Case Of The Swedish Brown Bear (Ursus Arctos). Available online at: http://urn.kb.se/resolve?urn=urn:nbn:se:su:diva- 173266 (accessed February 13, 2020).

Cinque, S. (2008). I Vargens Spår. Myndigheters Handlingsutrymme i Förvaltningen av Varg [In the Wolf Track: Administrative Discretion In Wolf Management]. $\mathrm{PhD}$ thesis, University of Gothenburg, Sweden.

Cinque, S. (2015). Collaborative management in wolf licensed hunting: the dilemmas of public managers in moving collaboration forward. Wildlife Biol. 21, 157-164. doi: 10.2981/wlb.00098

Council of Europe (1979). Convention on the Conservation of European Wildlife and Natural Heritage. Bern: Council of Europe. version of the manuscript to be published. AS-L and CR: main responsibility for acquisition of data.

\section{FUNDING}

The Swedish case study was funded by the Swedish Research Council (2014-1446). The Norwegian case study was funded by the Norwegian Research Council (2017-267982) and the Norwegian Agricultural Agency (Reindriftens Utviklingsfond: RUF 2016-41639).

\section{ACKNOWLEDGMENTS}

Our appreciation goes to all the individuals who have lent us their time and helped us gain important insight into the two case studies.

County Governor (2017). Statusbeskrivelse og Utviklingstrekk - Reindrift I Nordland, Vedlegg Til Revidert Forvaltningsplan For Rovvilt I Nordland. Available online at: https://www.fylkesmannen.no/contentassets/ 182bfdab512e474bab59136dbe15896d/vedlegg_c-til-forvaltningsplanen-

--statusbeskrivelse- og-utviklingstrekk---rein-i-nordland_januar-2017.pd (accessed September 17, 2019).

Díaz, C. L. (2010). The bern convention: 30 years of nature conservation in Europe. Rev. Eur. Comm. Int. Environ. Law 19, 185-196. doi: 10.1111/j.1467-9388.2010. 00676.x

Dondeyne, S., Kaarhus, R., and Allison, G. (2012). "Nature conservation, rural development and ecotourism in central mozambique: which space do local communities get?," in Making Sense of Place: Multidisciplinary Perspectives, eds I. Convery, G. Corsane, and P. Davis (Woodbridge: The Boydell Press), 291-301.

Eira, I. M. G., and Sara, M. N. (2017). Reindriftsnaeringens Erfaringsbaserte Kunnskap om Reindrift Og Rovvilt, Report, Utredning På Oppdrag Fra Sametinget. Fylkesmannen, Vadsø, Norway. Available online at: https:// www.fylkesmannen.no/Documents/Dokument\%20FMNO/Landbruk\%20og\% 20mat\%20dokumenter/Reindrift\%20dokumenter/Forskningsrapporter/Eira\% 20og\%20Sara\%202017_Reindriftsn\%C3\%A6ringens\%20erfaringsbaserte\% 20kunnskap\%20om\%20reindrift\%20og\%20rovvilt.pdf (accessed September 17, 2019).

Emerson, K., and Nabatchi, T. (2015). Collaborative Governance Regimes. Washington, DC: Georgetown University Press.

Epstein, Y. (2016). Favourable conservation status for species: examining the habitats directive's key concept through a case study of the swedish wolf. $J$. Environ. Law 28, 221-244. doi: 10.1093/jel/eqw006

European Commission (1992). Council Directive 92/43/EEC of 21 May 1992 on the Conservation Of Natural Habitats And Of Wild Fauna And Flora. Brussels: European Commission.

Failing, L., Gregory, R., and Harstone, M. (2007). Integrating science and local knowledge in environmental risk management: a decision-focused approach. Ecol. Econ. 64, 47-60. doi: 10.1016/j.ecolecon.2007.03.010

Falleth, E., and Hovik, S. (2009). Local government and nature conservation in Norway: decentralisation as a strategy in environmental policy. Local Environ. 14, 221-231. doi: 10.1080/1354983080269 2849

Folke, C. (2004). Traditional knowledge in social-ecological systems. Ecol. Soc. 9:7. Foucault, M. (1980). Power/Knowledge: Selected Interviews And Other Writings 1972-1977. New York: Pantheon Books.

Foucault, M. (1991). "Governmentality," in The Foucault Effect, eds G. Burchell, C. Gordon, and P. Miller (Chicago: The University of Chicago Press), 87-104.

Foucault, M. (2010). The Birth of Biopolitics: Lectures at the College de France, 1978-1979. New York: Palgrave McMillan. 
Gangaas, K. E., Kaltenborn, B. P., and Andreassen, H. P. (2013). Geospatial aspects of acceptance of illegal hunting of large carnivores in Scandinavia. PLoS One 8:e68849. doi: 10.1371/journal.pone.00 68849

Goldman, M. J., Nadasdy, P., and Turner, M. D. (eds) (2011). Knowing Nature: Conversations at the Intersection of Political Ecology and Science Studies. Chicago: The University of Chicago Press.

Hayes, T. M., and Persha, L. (2010). Nesting local forestry initiatives: revisiting community forest management in a REDD+ world. Forest Policy Econ. 12, 545-553. doi: 10.1016/j.forpol.2010.07.003

Hansson-Forman, K., Reimerson, E., Sjölander Lindqvist, A., and Sandström, C. (2018). Governing large carnivores - comparative insights from three different countries. Soc. Nat. Res. 31, 837-852. doi: 10.1080/08941920.2018.144 7179

Holmgren, L., Sandström, C., and Zachrisson, A. (2017). Protected area governance in Sweden: new modes of governance or business as usual? Local Environ. 22, 22-37. doi: 10.1080/13549839.2016.1154518

Hongslo, E., Hovik, S., Zachrisson, A., and Lundberg, A. K. A. (2016). Decentralization of conservation management in Norway and Swedendifferent translations of an international trend. Soc. Nat. Res. 29, 998-1014. doi: 10.1080/08941920.2015.1086456

IPBES (2019). The Global Assessment Report On Biodiversity And Ecosystem Services: Summary For Policymakers. Bonn: IPBES secretariat.

Ingold, T. (2000). The Perception of the Environment. New York, NY: Routledge.

IPCC (2019). Summary for Policymakers. In: Climate Change and Land: an IPCC Special Report On Climate Change, Desertification, Land Degradation, Sustainable Land Management, Food Security, And Greenhouse Gas Fluxes In Terrestrial Ecosystems. Rome: UNIPCC.

Joks, S., Henriksen, I. M., Mathisen, S. D., and Magga, O. H. (2006). Reintallet $i$ Vest-Finnmark: Forskningsbasert Vurdering Av Prosessen Rundt Fastsettelse Av Høyeste Reintall i Vest- Finnmark. Kautokeino: Nordisk Samisk Institutt.

Johnsen, K. I., Benjaminsen, T. A., and Eira, I. M. (2015). Seeing like the state or like pastoralists? Conflicting narratives on the governance of Sámi reindeer husbandry in finnmark, Norway. Norwegian J. Geogr. 69, 230-241. doi: 10.1080/ 00291951.2015 .1033747

Kløcker Larsen, R., Raitio, K., Stinnerbom, M., and Wik-Karlsson, J. (2017). Samistate collaboration in the governance of cumulative effects assessment: a critical action research approach. Environ. Impact Assess. Rev. 64, 67-76. doi: 10.1016/ j.eiar.2017.03.003

Krange, O., Odden, J., Skogen, K., Linnell, J. D. C., Stokland, H. B., Vang, S., et al. (2016). Evaluering av Regional Rovviltforvaltning - NINA Rapport 1268. New York, NY: Nina Alvarez.

Larson, A. M., and Ribot, J. S. (2005). "Democratic decentralisation through a natural resource lens: an introduction," in Democratic Decentralisation through a Natural Resource Lens, eds J. S. Ribot and A. M. Larson (New York, NY: Routledge), 1-25.

Länsstyrelserna (2018). [County Administrative Boards] Rovdjur $i$ norra Sverige. Förutsättningar, Förekomst Och Förvaltning. Available online at: https://www.lansstyrelsen.se/download/18.4e0415ee166afb593241fe77/ 1542790537498/Rovdjur\%20i\%20norra\%20Sverige.pdf (accessed September $17,2019)$.

Manor, J. (1999). The Political Economy of Democratic Decentralization. Washington, DC: The World Bank.

Mårald, E., Sandström, C., Rist, L., Rosvall, O., Samuelsson, L., and Idenfors, A. (2015). Exploring the use of a dialogue process to tackle a complex and controversial issue in forest management. Scand. J. For. Res. 30, 749-756. doi: $10.1080 / 02827581.2015 .1065343$

Ministry of Climate and Environment (2016). Norway's National Biodiversity Action Plan (Meld. St. 14). Available online at: https://www.cbd.int/doc/world/ no/no-nbsap-v4-en.pdf (accessed February 12, 2020).

Nadasdy, P. (2005). The anti-politics of TEK: the institutionalization of comanagement practice and discourse. Anthropologica 47, 215-232.

Neumann, A. (2017). "Sami participatory rights in area protection and management: The influence of the related CBD's programme in Finland and Norway," in Indigenous Rights in Modern Landscapes - Nordic Conservation Regimes in Global Context, eds L. Elenius, C. Allard, and C. Sandström (London, UK: Routledge), 200-215.
Norwegian Carnivore Regulation (2005). Forskrift om forvaltning av rovvilt.FOR2005-03-18-242, Hefte 4, 'Rovviltforskriften. Oslo, NW: Ministry of Climate and Environment.

Norwegian Government Proposition Ot. prp. nr. 52. (2008). Om Lov Om Forvaltning Av Naturens Mangfold (Naturmangfoldloven) (2008-2009). Olso: Ministry of Climate and Environment.

Primmer, E., and Kyllönen, S. (2006). Goals for public participation implied by sustainable development, and the preparatory process of the Finnish National Forest Programme. Forest Policy Econ. 8, 838-853. doi: 10.1016/j.forpol.2005. 01.002

Ragin, C. C. (1992). "Introduction: cases of 'what is a case," in What is A Case?, eds C. C. Ragin and H. S. Becker (Cambridge: Cambridge University Press), 1-17.

Reimerson, E. (2015). Nature, Culture, Rights: Exploring Space for Indigenous Agency in Protected Area Discourses. Ph.D. thesis, Dissertation, Umeå Universitet, Umeå.

Ribot, J., Agrawal, A., and Larson, A. (2006). Recentralizing while decentralizing: how national governments reappropriate forest resources. World Dev. 34, 1864-1886. doi: 10.1016/j.worlddev.2005. 11.020

Risvoll, C. (2015). Adaptive Capacity Within Pastoral Communities In The Face Of Environmental And Societal Change. Ph. D. thesis, University of Nordland, Bodø.

Risvoll, C., Fedreheim, G. E., and Galafassi, D. (2016). Tradeoffs in pastoral governance: challenges for biodiversity and adaptation. Pastoralism 6:51. doi: 10.1186/s13570-016-0051

Risvoll, C., and Hovelsrud, G. K. (2016). Pasture access and adaptive capacity in reindeer herding districts in Nordland, Northern Norway. Polar J. 6, 87-111. doi: 10.1080/2154896X.2016.1173796

Risvoll, C., and Kaarhus, R. (in press). "Struggling with 'clear zoning': dilemmas of predator-pastoral coexistence in Nordland, northern Norway," Indigenous Knowledges and the Sustainable Development Agenda, eds A. Breidlid, and R. Krøvel (London, NY: Routledge).

Rival, L. (ed.) (2001). The Social Life of Trees: Anthropological Perspectives on Tree Symbolism, 2nd Edn, New York, NY: Berg.

Rovbase (2019). Norwegian Environmental Authority. Population goals (Bestandsmål). Available online at: http://www.rovbase.no/Fakta/Bj\%C3\% B8rn?side $=$ Bestandsm\%C3\%A5l (accessed September 17, 2019).

Rutherford, S. (2007). Green governmentality: insights and opportunities in the study of nature's rule. Prog. Hum. Geogr. 31, 291-307. doi: 10.1177/ 0309132507077080

Sandström, C., Pellikka, J., Ratamäki, O., and Sande, A. (2009). Management of large carnivores in Fennoscandia: new patterns of regional participation. Hum. Dimen. Wildlife 14, 37-50. doi: 10.1080/10871200802304726

Sandström, C., Sjölander-Lindqvist, A., Pellikka, J., Hiedanpää, J., Krange, O., and Skogen, K. (2018). "Between politics and management: governing large carnivores in Fennoscandia," in Large Carnivore Conservation and Management: Human Dimensions, ed. T. Hovardas (London: Routledge), 269290.

Sametinget (2019). Renägare. Statistik Rennäring (Reindeer Owners, Statistics Reindeer Husbandry). Available online at: https://www.sametinget.se/statistik/ ren\%C3\%A4gare (accessed September 17, 2019).

Sara, M. N. (2001). Reinen - et Gode Fra Vinden. Karasjok: Davvi Girji.

Scott, J. C. (1998). Seing Like a State. London: Yale University Press.

Sjölander-Lindqvist, A. and Cinque, S. (2014). Dynamics of participation: Access, standing and influence in contested natural resource management. Partecipazione e Conflitto - The Open J. Sociopolitical Stud. 7, 360-383.

Shore, C., Wright, S., and Però, D. (eds) (2011). Policy Worlds: Anthropology and Analysis of Contemporary Power. New York, NY: Oxford University Press.

Sivertsen, T. R. (2017). Risk Of Brown Bear Predation On Semi-Domesticated Reindeer Calves. Diss. (Sammanfattning/Summary). Uppsala: Sveriges lantbruksuniv.

Sjölander-Lindqvist, A., Johansson, M., and Sandström, C. (2015). Individual and collective responses to large carnivore management: the roles of trust, representation, knowledge spheres, communication and leadership. Wildlife Biol. 21, 175-185. doi: 10.2981/wlb.00065 
Sjölander-Lindqvist, A. (2008). Local identity, science and politics indivisible: The Swedish wolf controversy deconstructed. J. Environ. Policy Plan. 10, 71-94.

Stoffle, R.W., Stoffle, B.W., and Sjölander-Lindqvist, A. (2013). "Contested time horizons", in Sustainability Assessment: Pluralism, Practice and Progress, eds A. Bond, A. Morrison-Saunders and R. Howitt (New York, NY: Routledge), 51-67.

Stortinget. 2003-2004. (2003). Parliament's Document Nr. 15: (2003-2004) Rovvilt i norsk natur. Oslo: Ministry of Climate and Environment.

Stortinget 2010-2011. (2010). Parliament's Document Nr. 8:163 S. (2010-2011) Representantforslag $163 \mathrm{~S}$. Available online at: https://www.stortinget.no/no/ Saker-og-publikasjoner/Publikasjoner/Representantforslag (accessed May 5, 2019).

Strand, G. H. (2016). Rovviltbestandenes Betydning For Landbruk Og Matproduksjon Basert På Norske Ressurser, Rapport 63/2016. Trondheim: Norsk institutt.

Strand, G.-H., Hansen, I., de Boon, A., and Sandström, C. (2019). Carnivore management zones and their impact on sheep farming in Norway. Environ. manage. 64, 537-552. doi: 10.1007/s00267-019-01212-4

Strang, V. (2009). Gardening the World: Agency, Identity, and the Ownership of Water. New York, NY: Berghahn.

Swedish Code of Statutes (2001). Viltskadeförordning (2001:724) [Wildlife Injuries Ordinance]. Ministry of Economic Affairs.

Swedish Code of Statutes (2009). Förordning (2009:1474) om viltförvaltningsdelegationer [Wildlife Management Delegation Ordinance]. Ministry of the Environment and Energy.

Swedish Code of Statutes (2010). Förordning (2010:242) om Ändring i Förordningen (2009:1474) Om Viltförvaltningsdelegationer [Ordinance on Change in the Wildlife Management Delegation Ordinance].

Swedish Environmental Protection Agency [SEPA] (2013). Förvaltningsverktyg för Förekomst Av Stora Rovdjur Baserat På En Toleransnivå För Rennäringen. Available online at: https://www.naturvardsverket.se/Documents/ publikationer6400/978-91-620-6555-3.pdf?pid=8051 (accessed August 28, 2019).

Swedish Environmental Protection Agency [SEPA] (2015). Strategy for Swedish Wildlife Management. Available online at: https://www.naturvardsverket.se/ Documents/publikationer6400/978-91-620-8797-5.pdf?pid=22001 (accessed August 28, 2019).

Swedish Government Bill (2008/09:210). En ny rovdjursförvaltning. Available online at: https://www.riksdagen.se/sv/dokument-lagar/dokument/ proposition/en-ny-rovdjursforvaltning_GW03210 (accessed September 17, 2019).

Swedish Government Bill (2009/10:155). Svenska miljömål - för ett effektivare miljöarbete. Available online at: https://www.regeringen.se/rattsliga-dokument/ proposition/2010/03/prop.-200910155/ (accessed September 17, 2019).

Swedish Government Official Reports (2012:22). Mål för Rovdjuren. SOU-Series. Available online at: https://www.regeringen.se/rattsliga-dokument/statensoffentliga-utredningar/2012/04/sou-201222/ (accessed September 17, 2019).

Swedish Government Official Reports (1999:25). Samerna - ett Ursprungsfolk $i$ Sverige. Frågan om Sveriges Anslutning Till ILO:s Konvention nr 169.
SOU-series. Available online at: https://www.regeringen.se/rattsliga-dokument/ statens-offentliga-utredningar/1999/03/sou-199925/ (accessed September 17, 2019).

Swenson, J. E., and Andrén, H. (2005). "“'A tale of two countries: large carnivore depredation and compensation schemes in Sweden and Norway"," in People and Wildlife: Conflict or Coexistence?, eds R. Woodroffe, S. Thirgood, and A. Rabinowitz (Cambridge: Cambridge University Press), 323-339. doi: 10.1017/ CBO9780511614774.021

Trouwborst, A., Fleurke, F. M., and Linnell, J. D. C. (2017). Norway's WolfPolicy and the bern convention on european wildlife: avoiding the "manifestly absurd". J. Intern. Wildlife Law Policy 20, 155-167.

United Nations (1992). Convention on Biological Diversity. Available online at: https://www.cbd.int/doc/legal/cbd-en.pdf (accessed April 29, 2020).

United Nations (2011). Sustainable Development in the 21st Century: Implementation of Agenda 21 and the Rio Principles, Detailed Report on the Implementation of Agenda 21, Department of Economic and Social Affairs. New York: United Nation.

United Nations (2018a). Norway's Sixth National Report to the United Nations Convention on Biological Diversity. Available online at: https://chm.cbd.int/pdf/ documents/nationalReport6/241229/4 (accessed February 12, 2020).

United Nations (2018b). Sweden's Sixth National Report to the United Nations Convention on Biological Diversity. Available online at: https://chm.cbd.int/ database/record?documentID=243293 (accessed February 12, 2020).

Vinzant, J. C., and Crothers, L. (1998). Street-level Leadership: Discretion and Legitimacy in Frontline Public Service. Washington, DC: Georgetown University Press.

Wenger, E. (1998). Communities of practice: learning, meaning and identity. J. Math. Teach. Educ. 6, 185-194. doi: 10.1023/A:1023947624004

Winter, S. C. (2007). "Implementation perspectives: status and reconsideration," in The Handbook of Public Administration, eds G. Peters and J. Pierre (London: Sage), 131-142.

Woodroffe, R., and Redpath, S. M. (2015). When the hunter becomes the hunted: effective predator management relies on social acceptability as well as scientific evidence. Conservation 348, 1312-1314. doi: 10.1126/science.aaa 8465

Zachrisson, A. (2009). Commons Protected for or From the People?: CoManagement in the Swedish Mountain Region? Ph.D. thesis, Dissertation, Statsvetenskapliga Institutionen, Umeå Universitet, Umeå.

Conflict of Interest: The authors declare that the research was conducted in the absence of any commercial or financial relationships that could be construed as a potential conflict of interest.

Copyright () 2020 Sjölander-Lindqvist, Risvoll, Kaarhus, Lundberg and Sandström. This is an open-access article distributed under the terms of the Creative Commons Attribution License (CC BY). The use, distribution or reproduction in other forums is permitted, provided the original author(s) and the copyright owner(s) are credited and that the original publication in this journal is cited, in accordance with accepted academic practice. No use, distribution or reproduction is permitted which does not comply with these terms. 